Original Research Paper

\title{
Steady State Groundwater Flow Modeling of an Ex-Landfill Site in Kuala Lumpur, Malaysia
}

\author{
${ }^{1}$ Mustapha Atta, ${ }^{2}$ Wan Zuhairi Wan Yaacob and ${ }^{3}$ Othman Bin Jaafar \\ ${ }^{1,2}$ Geology Programme School of Environmental Sciences and Natural Resources, Faculty of Science and Technology, \\ ${ }^{3}$ Department of Civil and Structural Engineering, Faculty of Engineering and Built Environment, \\ University Kebangsaan Malaysia, 43600 Bangi Selangor Darul Ehsan, Malaysia
}

Article history

Received: 19-01-2015

Revised: $30-07-2015$

Accepted: 06-08-2015

Corresponding Author:

Mustapha Atta

Geology Programme School of

Environmental Sciences and

Natural Resources,

Faculty of Science and

Technology, University

Kebangsaan Malaysia 43600

Bangi Selangor Darul Ehsan

Malaysia

Email: mustapha_atta@yahoo.com

\begin{abstract}
Effective and rational management of groundwater resources require adequate information on the groundwater flow interactions with surface water and chemical species in the flow regime. The hydrologic conditions beneath the unlined ex- landfill site in Jinjang Kuala Lumpur were investigated to understand the groundwater flow and geochemical setting in which contaminants transport in the groundwater may occur in the ex-landfill. The MODFLOW 2000 was used to construct the groundwater flow regime. The model was set up and calibrated as a three (3) layer steady-state MODFLOW model. The MODFLOW model revealed that the hydraulic gradient of the groundwater flow in the landfill site is to the north-east, towards Jinjang River which is located on the eastern part of the landfill. There is also groundwater movement towards the south-east of the landfill towards the Nanyang and Wahyu Ponds. It was concluded that quick action is deemed necessary to protect Jinjang River and Nanyang Pond which are hydraulically connected with the same aquifer and the geochemical setting in which contaminants transport may occur in the ex-landfill is in the same direction as the flow of the two water bodies. Recommendations are suggested to reduce the groundwater level by pumping below the height of the river bed, so that there is no contamination to the river and pond via recharge of groundwater into the river, instead the river should recharge to the groundwater.
\end{abstract}

Keywords: Groundwater Flow Models, Leachate Contamination, MODFlOW, Taman Beringin Malaysia

\section{Introduction}

Pollution, mismanagement, over depletion, climatechange, escalating population, national development projects, industrial and agriculture development are among the major problems linked to water quality issues around the globe. The situation has heightened to a climax where water is being hijacked by upstream users and multinational through water diversions and its conservations by massive dam constructions. However, intensified concerns have been raised severally due to the issues related to environmental and health impacts of surface and groundwater pollution. This is attributed mainly to anthropogenic influences on the earth environment. One of the frequently reported cases have been due to waste buried in landfill leading to the generation of leachate and the subsequent outflow from landfill sites to groundwater. On the other hand, surface water quality may be impacted via groundwater flow or vice versa. Large numbers of toxins are leached into these fresh water ways and are eventually submerge to the groundwater and inevitably to pumping well and finally our drinking water which are very harmful to human life, plant and animals or to the ecosystem in general (Gondwe, 2010). Therefore both surface water and groundwater are two vital and interconnected water bodies that relates to each other both in terms of quality and quantity. However, either surface or groundwater, the general goal is to make certain that adequate supplies of water of good quality are made available for all people, the ones living today and future generations, while preserving required quantity and quality of water flow to sustain crucial functions of ecosystems (Björklund, 2001). 
Groundwater models therefore play an important role in the development and management measures (Zhou and Li, 2011). The tools aid in the understanding of the surface and groundwater flow/interaction and the governing phenomenon. According to Zhou and $\mathrm{Li}$ (2011) various groundwater flow models are useful as: (1) Interpretative tools for investigating groundwater system dynamics and understanding the flow patterns; (2) assimilation tools for analyzing responses of the groundwater system to stresses; as supporting tools for planning field data collection and designing practical solutions; (3) as management tools for assessing alternative polices; and (4) as visualization tools for communicating key messages to public and decision-makers.

The main issue with the Taman Beringin exlandfill stems from the fact that during the operation of the landfill, minimal environmental safeguards were not in place; landfilling were carried out without basal liners to protect the groundwater and the environment. Consequentially, despite the closure and restoration of the landfill, there is still the problem of rain water which still passes through the waste and produces leachate. The seepage of leachate discharges directly into the groundwater and Jinjang River which is a tributary of a major river in the city capital Kuala Lumpur. This paper therefore investigate the groundwater flow beneath the Taman Beringin exlandfill site using the MODFLOW modeling approach calibrated in steady state groundwater flow for assessment of the site to fully understand the geochemical settings in which contaminants transport from the ex-landfill may occur.

\section{Materials and Methods}

\section{Site Description}

The study area is a defunct landfilled site that has been closed and restoration work has long begun in 2006. Currently, there are ongoing activities and construction projects carried out to restore the site. The Taman Beringin ex-landfill site measures about 30-hectare (ha) and located at North Jinjang; about 10 $\mathrm{km}$ North West of Kuala Lumpur Federal Capital Territory of Malaysia at latitude $03^{\circ} 13.78^{\prime}$ North and longitude $101^{\circ} 39.72$ ' East (Atta et al., 2015). The elevated total height is almost $40 \mathrm{~m}$ from the foot of the landfill (90 m above sea level). Atta et al. (2015) pointed out that ground level reaches up to $55.72 \mathrm{mRL}$ in the landfill site. However, the ground level at the capped area of the landfill, which forms a plateau at the top central part of the landfill, is deeper and about $87.86 \mathrm{mRL}$ (Uni-Technologies Sdn. Bhd., 2013). There is also the Taman Beringin Transfer Station on the northern part, owned by the management authorities known as Dewan Bandaraya Kuala Lumpur (DBKL) or Kuala Lumpur City Hall (KLCH). In the worst case, housing developments are concentrated especially on the north-east, south and south-east of the surrounding area of the landfill.

Precipitation is experienced throughout the year. However, droughts situations experienced in recent years have shown that the situation could be very unpredictable. Generally, the site is associated with two monsoons: The southeast monsoons (between March-April) and southwest monsoon seasons (October-November). Total amount of precipitation averages $2366.2 \mathrm{~mm}$ (93.2 in). Temperature reaches $28-32^{\circ} \mathrm{C}$. The north-western part of Klang Valley where the landfill is situated is topographically surrounded by granite, metasedimentary of Howthornden and Kenny Hills Formations and particularly Kuala Lumpur Limestone. This formations shape up the topography of the site. The Kuala Lumpur Limestone is underlain by the fluvial deposits of the area. The fluvial deposits in this particular area form a topographic surface of generally flat with slightly sloping down-gradient towards the Southwest. These lithological formations and topographic surface also play the important roles in developing the regional groundwater system for Kuala Lumpur.

The Sungai Jinjang (or Jinjang River) runs along the north-east boundaries of the site. In addition to Jinjang River, there are also several water bodies such as Nanyang and Wahyu Ponds which are connected to this river on the east and south eastern part of the landfill (Fig. 1b). The topography map of the study area shows that the northern area has higher elevation than the southern part and a general trend of regional groundwater water movement in the study area is potentially towards the South-east. In contrast, a detail study of groundwater resource in Kuala Lumpur by Stek (2008) showed that the groundwater movement in Kuala Lumpur area is towards the Southwest. Although, this trend is much appreciated. However, on a small scale (the scale that is used in the groundwater modelling); the flow can be on the same direction or any other directions. Within the landfill, the aquifer in the site is a shallow sandy type of about 5-10 $\mathrm{m}$ thickness and inclusive of deeper fractured bedrock limestone. The bedrock of the study area is comprised of limestone which also acts as a good aquifer for groundwater. Figure 1a shows Taman Beringin Landfill physical location relation to Kuala Lumpur and Fig. 1b shows Taman Beringin and the position of the boreholes used for the study. 


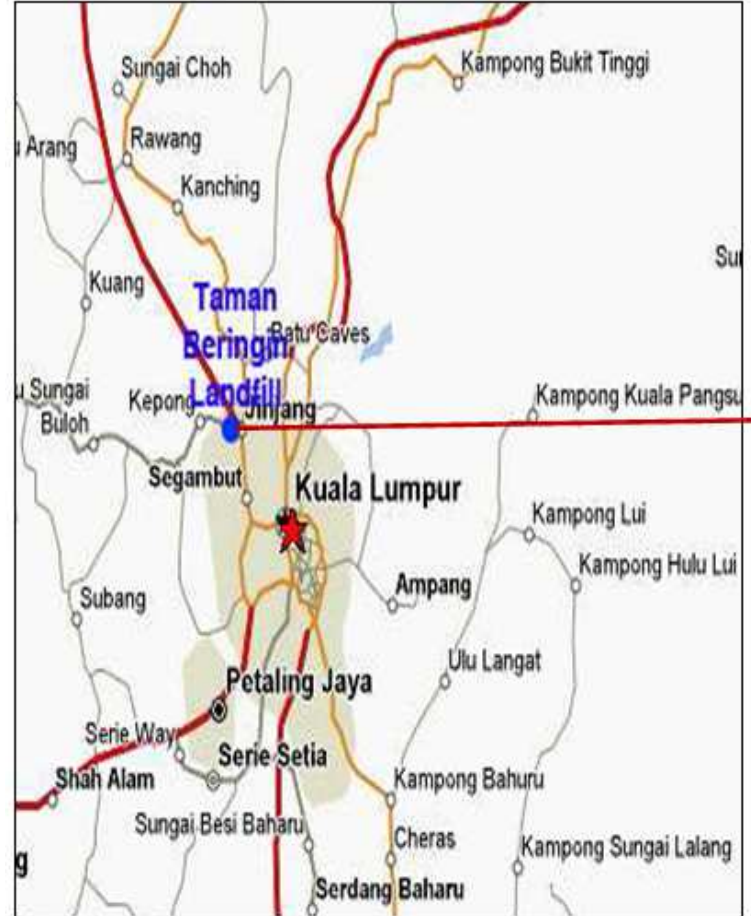

(a)

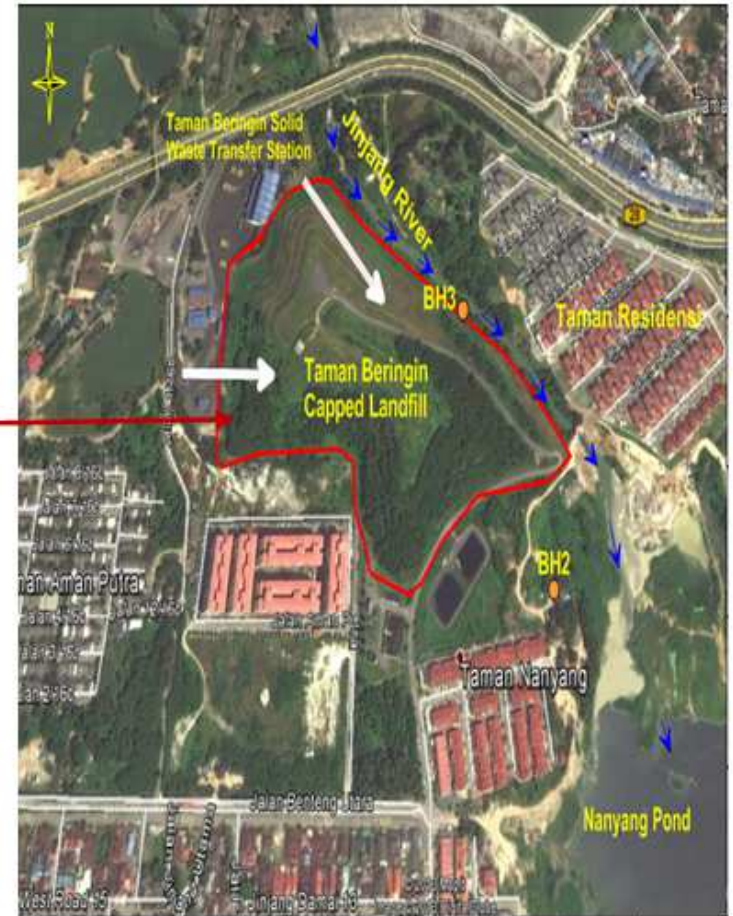

(b)

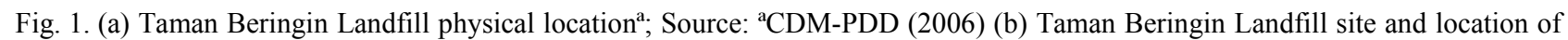
boreholes used for the study; Source: Adapted from Wan Yaacob (2011)

\section{Model Description}

The Taman Beringin landfill site groundwater flow regime was modeled using the visual MODFLOW modular finite-difference flow) approach Pro Version 2010. The Visual MODFLOW is a computer code that can be used to develop simple to complex three dimensional groundwater flow, fate and transport models of hydrogeological environment. The software was developed by McDonald and Harbaugh (1988) and is supported by the Modular Three-Dimensional Multispecies (MT3DMS) transport model developed by Zheng (1990). However, the software is maintained by the United States Geological Survey. Furthermore, Visual MODFLOW is a graphical 3D groundwater flow and contaminant transport modeling software for MODFLOW, MODPATH, MT3DMS and RT3D. With the Win PEST the software allows automatic calibration techniques. The engine codes: MODFLOW, MODPATH and MT3DMS are capable of solving the groundwater flow equation with powerful graphical interface.

\section{Conceptual Groundwater Model}

The conceptual groundwater model adapted for the Taman Beringin landfill site was developed based on the available information on drilling investigations. The study area is modeled using three layers. The geological strata of Taman Beringin Landfill comprised of three layers namely sandy silt at the top $(5 \mathrm{~m})$, silty sand in the middle $(15 \mathrm{~m})$ and finally silty clay at the bottom $(10 \mathrm{~m})$. The information of the geological strata was collected from the borehole report produced by Charita Sdn. Bhd. (2011). Two boreholes drillings that were drilled to the maximum depth of $30 \mathrm{~m}$ provide adequate information about the upper geologic strata of the study area. However, based on five boreholes drilled in this study the movement of groundwater is in the sandy sand formation. The bedrock of study area comprises of limestone which also acts as a good aquifer for groundwater.

\section{Modflow Computer Set Up}

The total model area is more or less square with dimensions of approximately $694 \mathrm{~m}$ wide and $678 \mathrm{~m}$ long. The model grid statistics consists of 30 rows and 30 columns. The grids are evenly spaced at approximately $55 \times 54 \mathrm{~m}$. At some places, the row and column of the grids were refined to give more detail and smooth profile of the model. The grid is aligned N-S and W-E. River and all ponds surrounding the site are used to represent the horizontal extent of the Modeled domain. This area head boundary. The right side of the Jinjang River which is remote from the river is 
considered as inactive cells. The physical model boundaries are summarized as follows:

- Western model boundary is a pond

- Eastern model boundary is a river

- South-east model boundary is a pond

- The north model boundary is also a pond is regarded as the natural drainage basin that encloses the Taman Beringin Landfill. Pond (water bodies) on the north and west of the model are considered as constant Table 1 summarizes the flow and transport parameters used in the model

The surface top elevation is obtained from the elevation survey conducted at this site. The middle and bottom elevation was estimated from the thickness of these layers as observed in Borehole drilling by Charita Sdn. Bhd. (2011) and GPS reading and elevation from goggle earth were also used to get the elevation readings of the study area (Table 1). Total precipitation in Kuala Lumpur area is 2500 $\mathrm{mm} /$ year as prescribed by White et al. (2003). Therefore, the total recharge to groundwater is estimated to be about $15 \%$ (375 mm/year) of the total annual precipitation in Kuala Lumpur area. The water table is about 2-3 m below the ground surface. The hydraulic conductivity values for all layers are estimated based on the material type of each layer (Table 1). Layer 1 is modeled as impermeable (Sandy silt); Layer 2 model is regarded as porous formation and acts as confined aquifer of silty sand. Layer 3 , is considered as another impermeable layer. In this study, modeling is focused on shallow aquifer that is present in the 2 nd layer of silty sand formation. The landfill is underlain by limestone. The limestone formation is not included in the model and the borehole drilled at this site has failed to reach this limestone formation because it is located far deeper. The depth is estimated to be deeper than $30 \mathrm{~m}$. The base of the model is therefore set as no flow boundary conditions.

\section{Groundwater Flow Equation}

The flow equation for three-dimensional saturated flow in porous media is governed by the Equation 1 according to Kumar (2002):

$$
\frac{\partial}{\partial x}\left(k_{x x} \frac{\partial h}{\partial x}\right)+\frac{\partial}{\partial y}\left(k_{y y} \frac{\partial h}{\partial y}\right)+\frac{\partial}{\partial z}\left(k_{z z} \frac{\partial h}{\partial z}\right)-Q=S s \frac{\partial h}{\partial t}
$$

\section{Where:}

$$
\begin{aligned}
K_{x x}, K_{y y}, K_{z z}= & \begin{array}{l}
\text { Hydraulic conductivity along the } \mathrm{x}, \mathrm{y}, \mathrm{z} \\
\text { axes which are assumed to be parallel to } \\
\text { the major axes of hydraulic conductivity }
\end{array} \\
= & \text { Piezometric head } \\
= & \text { Volumetric flux per unit volume } \\
& \text { representing source/sink }
\end{aligned}
$$

\begin{tabular}{|c|c|c|c|c|c|}
\hline Layer/Soil parameters & Layer 1 & Layer 2 & Layer 3 & Method & References \\
\hline Soil description & Sandy silt & Silty sand & Silty clay/Clay & $\begin{array}{l}\text { BS 1377-2:1990. Methods of test } \\
\text { for soils for civil engineering } \\
\text { purposes. Classification tests. }\end{array}$ & BS 1377-2 (1990) \\
\hline Layer elevation & $5 \mathrm{~m}$ & $15 \mathrm{~m}$ & $10 \mathrm{~m}$ & Soil drilling & Charita Sdn. Bhd. (2011) \\
\hline $\begin{array}{l}\text { Horizontal hydraulic } \\
\text { conductivity, } \mathrm{K}_{\mathrm{x}}(\mathrm{m} / \mathrm{sec})\end{array}$ & $1 \times 10^{-7^{a}}$ & $1 \times 10^{-5}$ & $1 \times 10^{-8}$ & $\begin{array}{l}\text { Insitu falling head } \\
\text { permeability test }\end{array}$ & Wan Yaacob (2011) \\
\hline $\begin{array}{l}\text { Horizontal hydraulic } \\
\text { conductivity, } \mathrm{K}_{\mathrm{y}}(\mathrm{m} / \mathrm{sec})\end{array}$ & $1 \times 10^{-7}$ & $1 \times 10^{-5}$ & $1 \times 10^{-8}$ & $\begin{array}{l}\text { Insitu falling head } \\
\text { permeability test }\end{array}$ & Wan Yaacob (2011) \\
\hline $\begin{array}{l}\text { Horizontal hydraulic } \\
\text { conductivity, } \mathrm{K}_{\mathrm{z}}(\mathrm{m} / \mathrm{sec})\end{array}$ & $1 \times 10^{-8}$ & $1 \times 10^{-6}$ & $1 \times 10^{-9}$ & $\begin{array}{l}\text { Insitu falling head } \\
\text { permeability test }\end{array}$ & Wan Yaacob (2011) \\
\hline Specific yield $\left(\mathrm{S}_{\mathrm{y}}\right)$ & 0.2 & 0.33 & 0.06 & Pumping test method & Wan Yaacob (2011) \\
\hline Specific storage $\left(\mathrm{S}_{\mathrm{s}}\right)$ & $2.6 \times 10^{-3}$ & $4.9 \times 10^{-4}$ & $2.6 \times 10^{-3}$ & Pumping test method & Wan Yaacob (2011) \\
\hline Total porosity & 0.45 & 0.43 & 0.42 & $\begin{array}{l}\text { ASTM F1815 - 11 } \\
\text { Standard test methods for saturated } \\
\text { Hydraulic conductivity, water retention, } \\
\text { Porosity and bulk density of athletic } \\
\text { Field rootzones. active standard } \\
\text { ASTM standard ASTM F1815 }\end{array}$ & $\begin{array}{l}\text { Wan Yaacob (2011); } \\
\text { Aimrun et al. (2004) }\end{array}$ \\
\hline Effective porosity & 0.20 & 0.33 & 0.06 & $\mathrm{~B}$ & $\begin{array}{l}\text { Wan Yaacob (2011); } \\
\text { Aimrun et al. (2004) }\end{array}$ \\
\hline Recharge (mm/year) & 375 & 375 & 375 & Estimated Recharge $=15-20 \%$ of rainfall & White et al. (2003). \\
\hline Dispersion & \multicolumn{3}{|c|}{$\begin{array}{l}\text { Longitudinal dispersivity }=10 \text {, Horizontal } \\
\text { to longitudinal ration }=0.1 \text {, Vertical to } \\
\text { longitudinal ratio }=0.01 \text {, Molecular } \\
\text { diffusion coefficient }=0.0\end{array}$} & $\begin{array}{l}\text { Estimate from the rock lithology and } \\
\text { types of contaminants }\end{array}$ & Wan Yaacob (2011) \\
\hline
\end{tabular}

Ss $\quad=$ Specific storage coefficient defined as the volume of water released from storage per unit change in head per unit volume of porous material

Table 1. The flow and transport parameters used in the model 


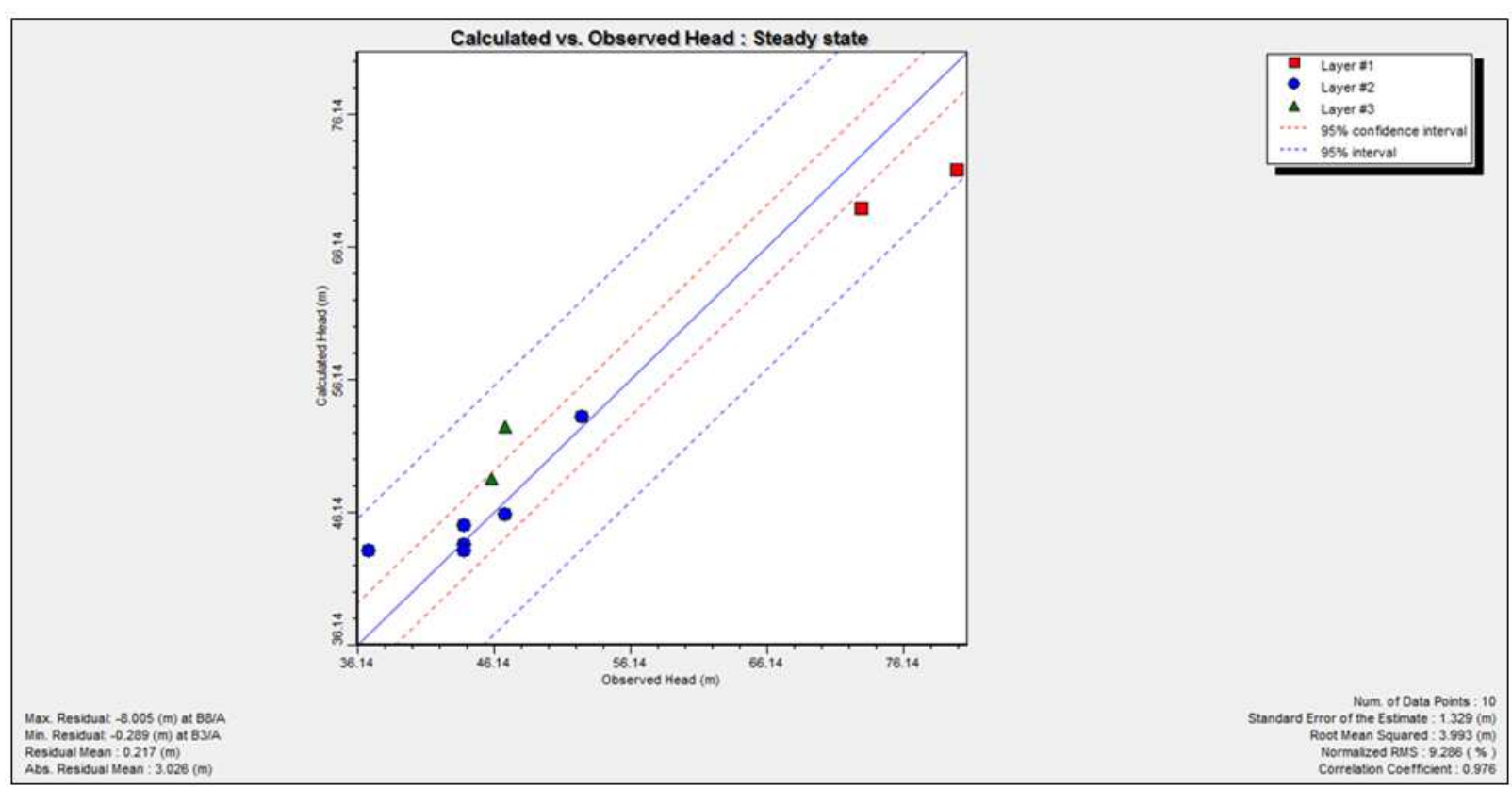

Fig. 2. Observed head and model calculated head

\section{Steady-State Model Calibration}

Taman Beringin groundwater flow was calibrated as steady-state groundwater flow model. The calibration of the hydraulic head fields of the study area were based on fieldmeasured values reported by Cypark Sdn Bhd (2003). Figure 2 shows the excellent agreement between 10 points data of observed head and model calculated head.

The correlation coefficient of the data obtained was accepted as 0.976 and it indicates that the simulated value is well correlated with the measured values. The mean error in calibration is $1.329 \mathrm{~m}$, indicating that the calibrated model only slightly overestimates the observed head.

\section{Model Assumptions}

The model was developed based on the following assumptions:

- Groundwater flow is assumed to be at steady state

- Hydraulic conductivity is assumed to be uniform and isotropic in horizontal plane

- Vertical hydraulic conductivity is assumed to be one-tenth the horizontal hydraulic conductivity for all geologic units

- The depth of Nanyang Pond is assumed to around $4 \mathrm{~m}$. if the depth of Nanyang Pond is bigger than $4 \mathrm{~m}$, the model is assumed to be affected and the groundwater will flow largely towards the Nanyang Pond

- Recharge is assumed to be uniformly distributed over the model domain and at steady state

- The base of the model is assumed to be no flow boundary (impermeable)

\section{Results and Discussion}

Figure $3 \mathrm{a}$ to $\mathrm{c}$ shows the contour of equipotential lines (groundwater head) and groundwater velocities for the three modeled layers. Layer 1 represents the groundwater and significant mound of leachate within the waste mass. The highest water level at the top of the landfill provides higher local hydraulic gradient outwards from the landfill towards all directions. Figure $3 b$ is the equipotential contour for Layer 2; this layer shows the overall trend of groundwater flow or hydraulic gradient which appears to be to the north-east and slightly south-east, towards the River Jinjang and Nanyang Pond. The groundwater velocity in this layer is higher compared to other layers. This is not surprising because Layer 2 is a confined aquifer with hydraulic conductivity $1 \times 10^{-5} \mathrm{~m} / \mathrm{sec}$ ) (see Table 1). The same equipotential trend is observed in Fig. $3 \mathrm{c}$ which is the Layer 3. In this layer the groundwater velocity is much smaller due to the low flow properties of this layer (i.e., clay). The layer plays very important role as an impermeable zone to give natural protection on the deeper aquifer formation against polluted groundwater flow. This is absolutely true because the aquifer (groundwater zone) is underlain by the impermeable layer (silty clay) with low hydraulic conductivity $\left(10^{-8} \mathrm{~m} / \mathrm{sec}\right)$. The main layer in focus is layer 2 . This second layer is the aquifer at the Taman Beringin landfill site where the impact of contamination direct from the leachate will be severe. This layer is further emphasized in Fig. 4-7. Figure 4 shows the plan view of the layer 2 that shows the equipotential lines and the velocity vector of groundwater flow. 


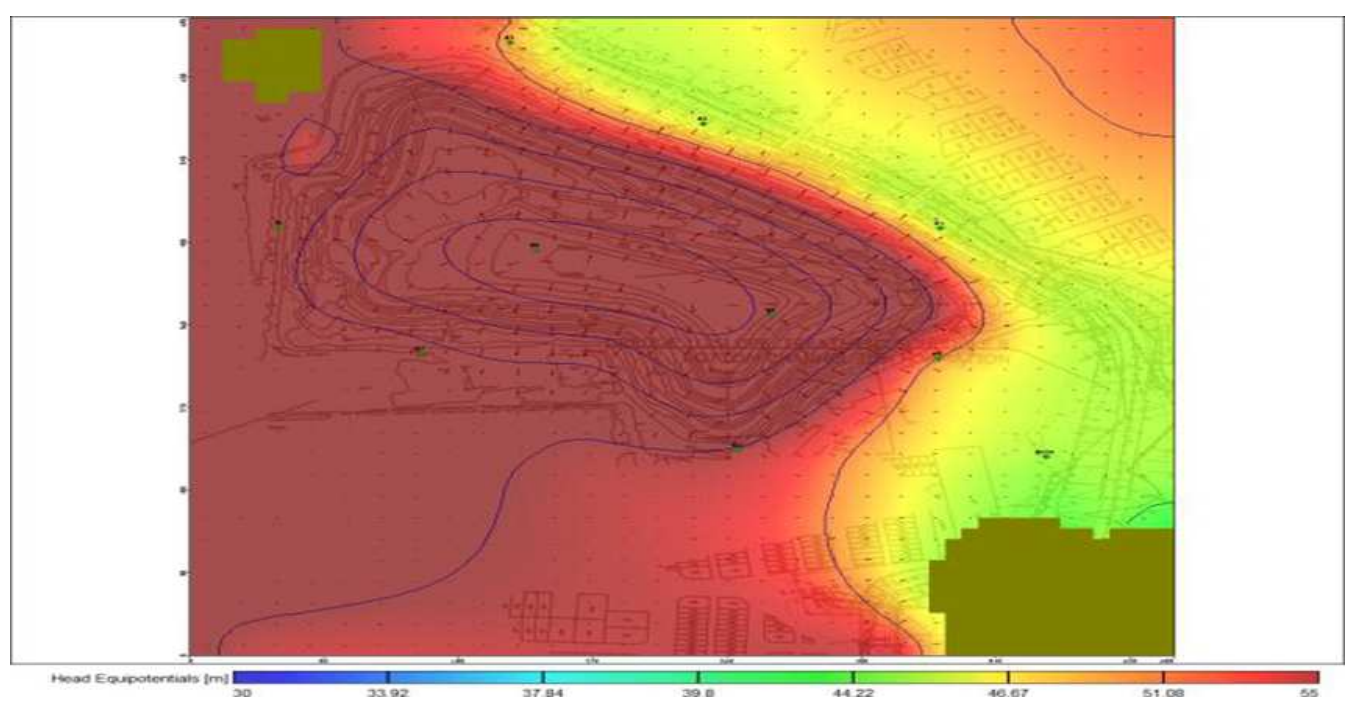

(a)

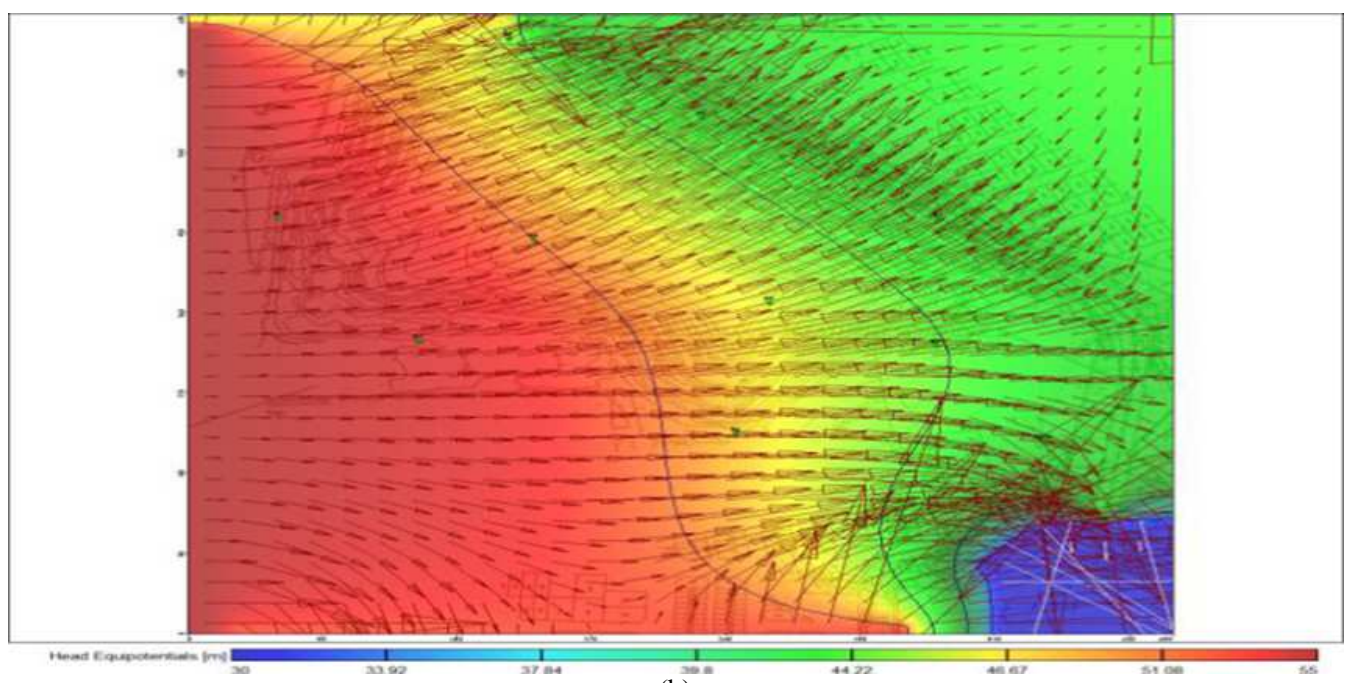

(b)

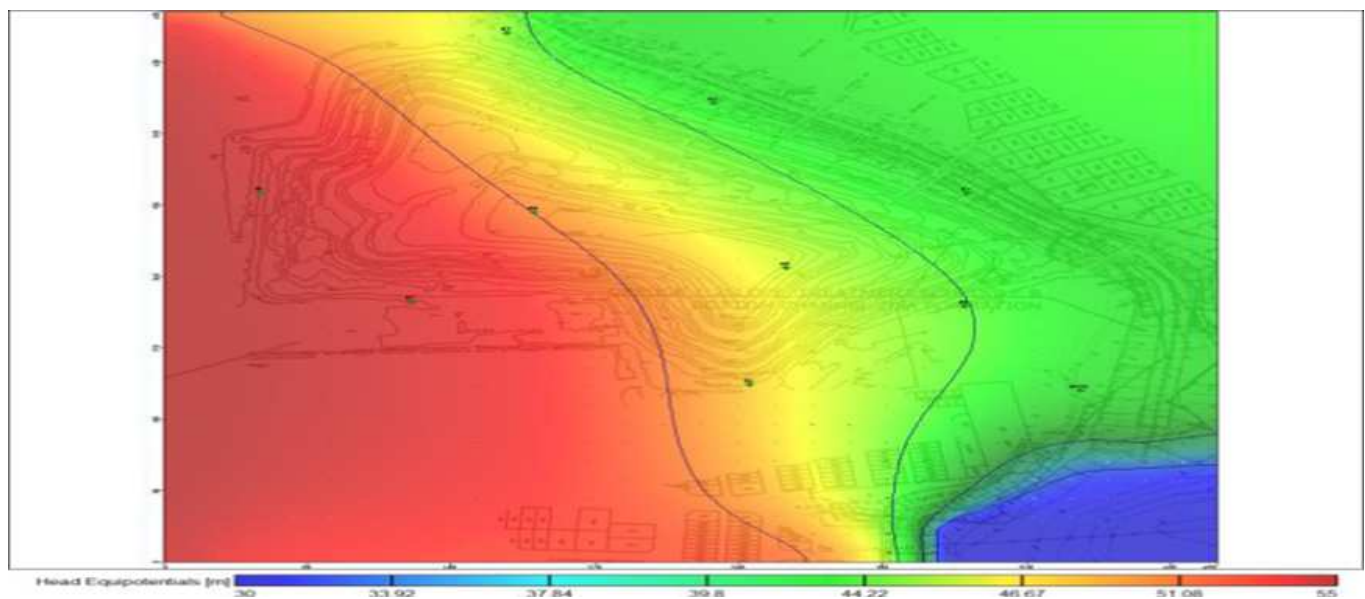

(c)

Fig. 3. (a) Layer (b) Layer 2 (c) Layer 3 


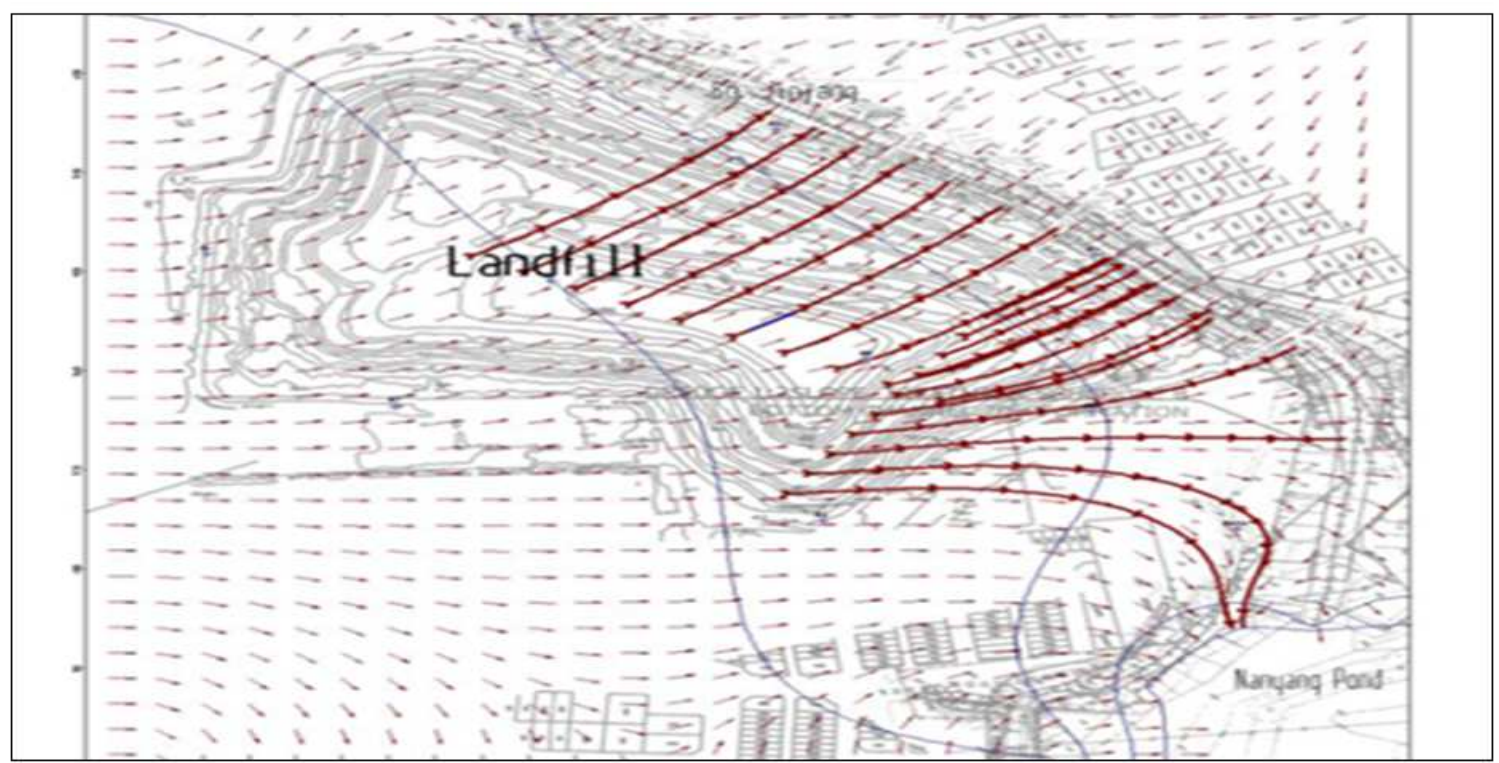

Fig. 4. Layer 2 (The plan view) shows the velocity of groundwater flow and migration pathway of particles

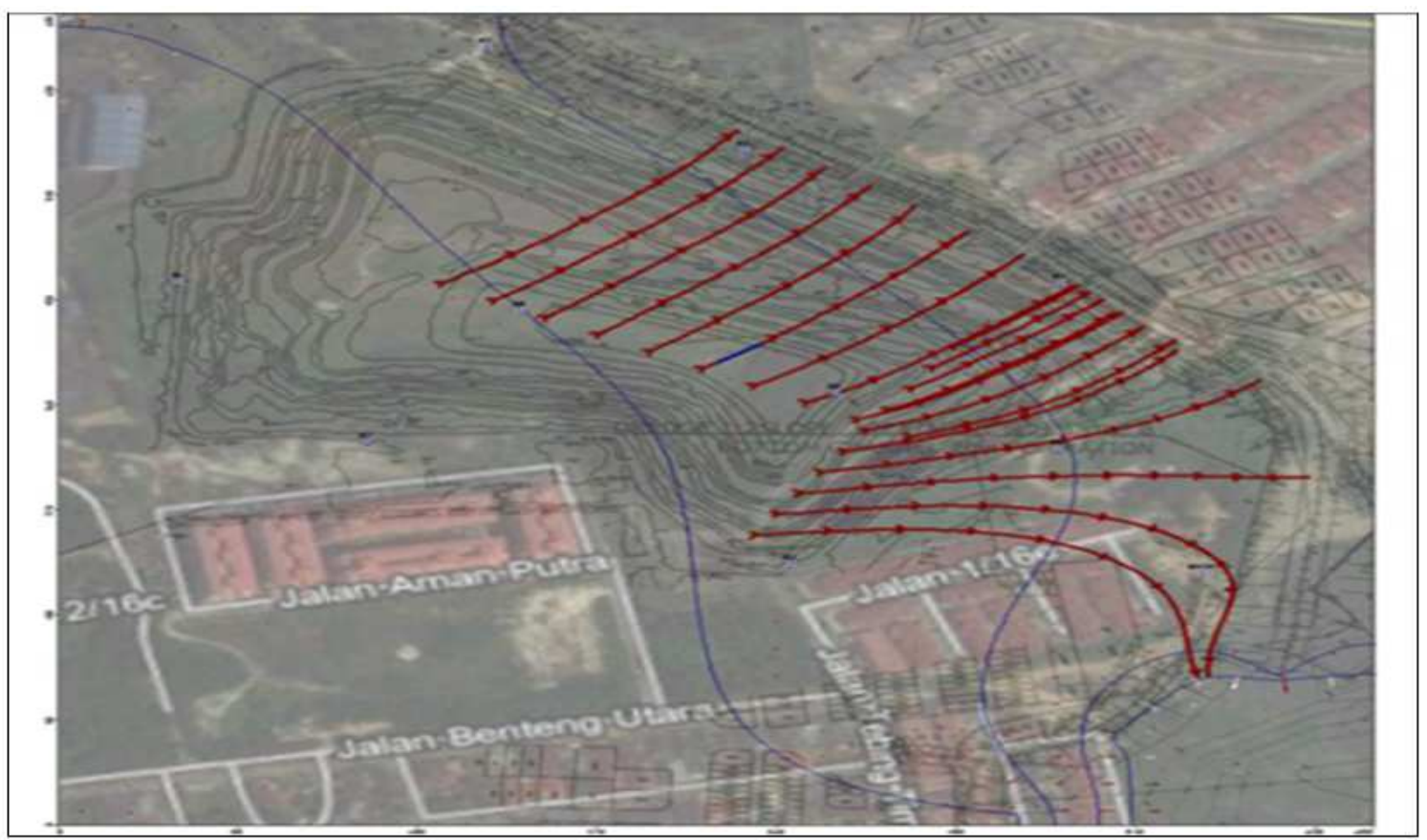

Fig. 5. (A combination of aerial photo and site map) clearly indicate the movement of groundwater at this landfill in layer

Bold brown lines indicate the movement of particles along the groundwater flow which is largely towards River Jinjang while Fig. 5 shows a combination of aerial photo and site map (overlay together) to clearly indicate the movement of groundwater at this landfill, which is towards Sg Jinjang and slightly shift toward Nanyang pond on the south side Fig. 6 shows a cross section of the model along west-east/x-axis (Row 41) showing the path line of the particles towards River Jinjang. The section clearly shows the pathways of particles in the 2nd layer that move towards Sg. Jinjang. Another section (Fig. 7) along the y-axis (north-south) shows the bidirection of particle pathways which is towards the Sg. Jinjang and Nanyang Pond. Overall, the groundwater of the area is best displayed using 3-D model as presented in Fig. 8 the 3-D view of the Taman Beringin Landfill indicates the movement of groundwater towards the eastern side towards $\mathrm{Sg}$. 


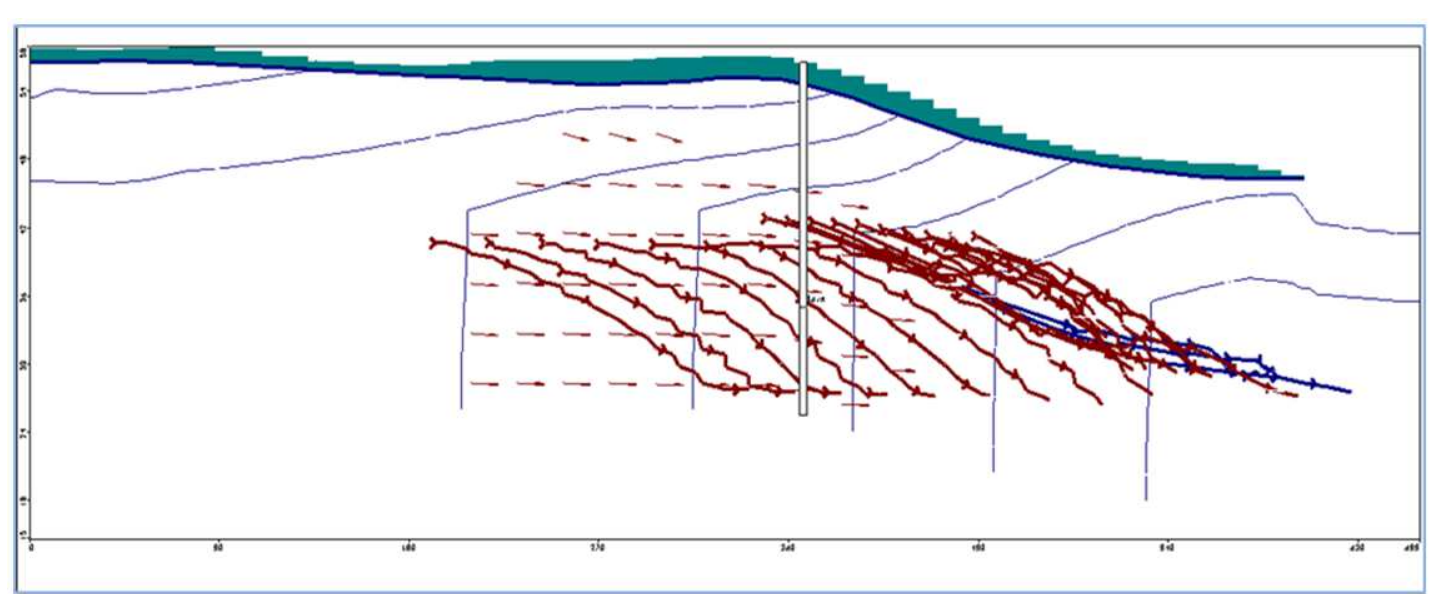

Fig. 6. A cross section of the model along west-east/x-axis (View at Row 41) showing the path line of the particles towards Jinjang River

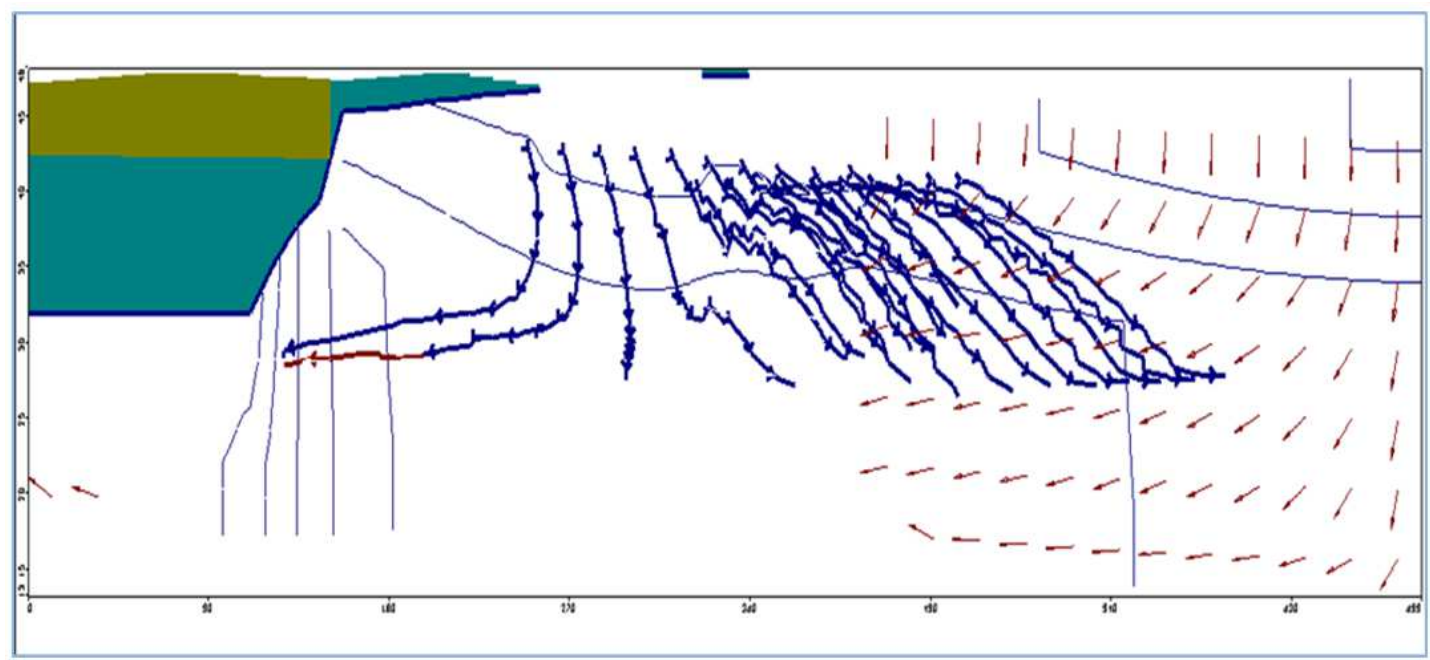

Fig.7. A view of particle movement towards Sg. Jinjang on the right side and Nanyang Pond on the left side (at Column 26 of the model)

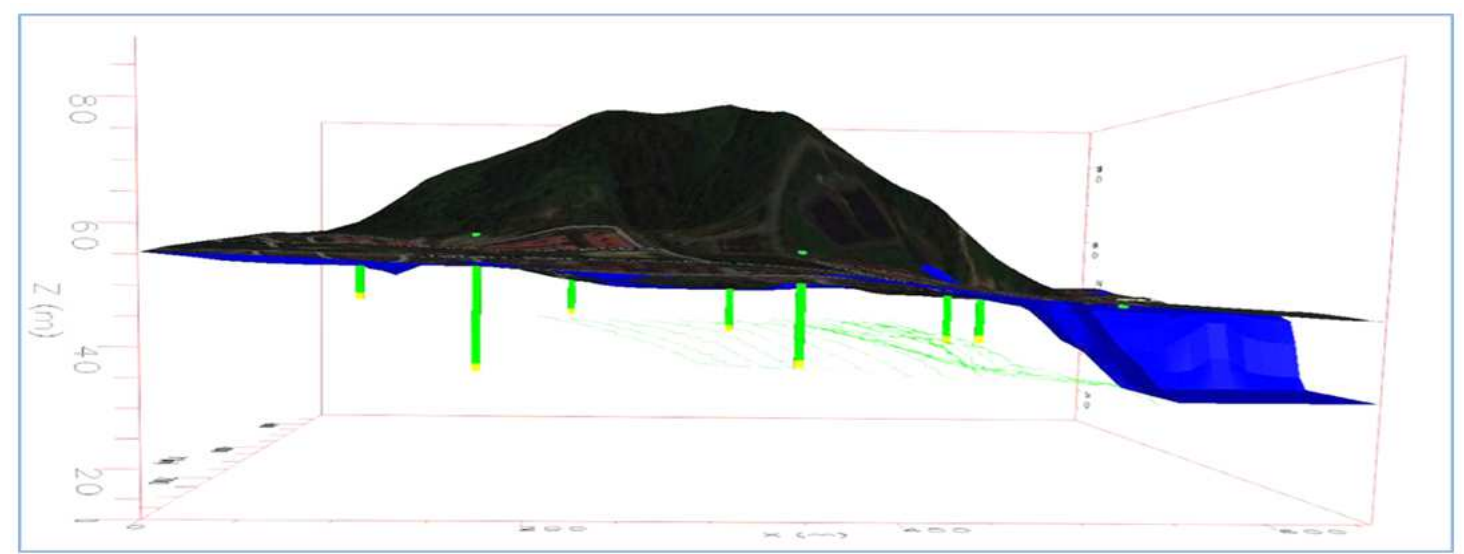

Fig. 8. Three dimensional view of the Taman Beringin Landfill indicating the movement of groundwater towards the eastern side towards Sg. Jinjang and Nanyang Pond ((Blue colour represents the water body of Jinjang River and Nanyang pond) 
Jinjang and Nanyang pond Blue color represents the water body of Sg. Jinjang and Nanyang Pond). Other information shown is seven boreholes (marked as columns of green and yellow) and the direction of particles (light green).

\section{Conclusion}

The MODFLOW model provides an excellent representation of the groundwater flow which revealed that the direction of groundwater flow is largely towards River Jinjang and Nanyang Pond located on the eastern part of the landfill. Based on the groundwater model, River Jinjang and Nanyang Pond are hydraulically connected with the same aquifer underneath the Taman Beringin Landfill.The model also indicated that river and water bodies are more vulnerable to contaminants migration from the layer 2 aquifer where the groundwater velocity is higher relative to layer 1 and layer 3. River Jinjang and Nanyang pond must be kept hydrochemically safe. Therefore, it is recommended that the groundwater level must be reduced (by pumping) below the height of the river bed, so that there is no recharge of groundwater into the river, instead the river should recharge to the groundwater and this will ensure there is no contamination to the river. Overall the the model is created based on limited amount of subsurface data. More data are still needed to re-calibrate and validate the model. However, the model presented here is enough to provide general information about the hydrogeological regime in the Taman beringin Landfill site.

\section{Acknowledgement}

The authors wish to acknowledge support of Faculty Science and Technology UKM and the financial support of the University Kebangsaan Malaysia (UKM) under the grant code: FRGS/A/2012/STWN01/UKM/01/1 and DPP-2014-078.

\section{Author's Contributions}

Mustapha Atta: Participated in the data-analysis and contributed to the writing of the manuscript.

Wan Zuhairi Wan Yaacob: Participated in all experiments, coordinated the data analysis and organized the study.

Othman Bin Jaafar: Participated in the dataanalysis, responsible for idealistic, editing of manuscript.

\section{Ethics}

This article is original and contains unpublished material. All authors have read and approved the manuscript and no ethical issues involved.

\section{References}

Aimrun, W., M.S.M. Amin and S.M. Eltaib, 2004. Effective porosity of paddy soils as an estimation of its saturated hydraulic conductivity. Geoderma, 121: 197-203. DOI: $10.1016 /$ j.geoderma.2003.11.010

ASTM F1815, 2011. Standard Test Method for Saturated Hydraulic Conductivity, Water Retention, Porosity and Bulk Density of Athletic Field Rootzones. ASTM International, West Conshohocken, PA.

Atta, M., W.Z. Wan Yaacob and O. Bin Jaafar, 2015. The potential impact of leachate-contaminated groundwater of an ex-landfill site at Taman Beringin Kuala Lumpur, Malaysia. Environ. Earth Sci., 73: 3913-3923.

DOI: $10.1007 / \mathrm{s} 12665-014-3675-\mathrm{x}$

Björklund, G., 2001. Water management in developing countries-policy and priorities for EU development cooperation. SIWI Report 12. Stockholm International Water Institute (SIWI).

BS 1377-2, 1990. Methods of test for soils for civil engineering purposes. Classification Tests, British Standard.

Charita Sdn. Bhd., 2011. Laporan Kerja Penyiasatan Tapak untuk Kerja Kawalan Kuantiti and Kualiti Air sungai bagi Projek River of Life (ROL).

CDM-PDD, 2006. Version 03-1 in effect as of 28 July 2006. Clean Development Mechanism Project Design Document.

Cypark Sdn Bhd, 2003. Technical Report. Cadangan Pemulihan dan Guna Semula Tapak Pelupusan Sisa Pepejal Taman Beringin, Kuala Lumpur. Restoration Master Plan

Gondwe, B.R.N., 2010. Exploration, modelling and management of groundwater dependent ecosystems in Karst: The Sian Ka'an case study, Yucatan, Mexico. PhD Thesis, Technical University, Denmark.

Kumar, C.P., 2002. Groundwater flow models. Scientist 'E1' National Institute of Hydrology Roorkee247667 (Uttaranchal) publications.

McDonald, M.G. and A.W. Harbaugh, 1988. A modular three-dimensional finite-difference ground-water flow model. Techniques of Water Resources Investigations of the United States Geological Survey Book 6.

Stek, P.E., 2008. Urban groundwater extraction in Kuala Lumpur, Malaysia. M.A Thesis. Civil Engineering and Management, University of Twente Netherlands. 
Uni-Technologies Sdn. Bhd., 2013. Mengkaji Kesesuaian Tapak Bagi Pembinaan Loji Rawatan Termal di Kawasan Tapak Pelupusan Sisa Pepejal Taman Beringin, Jinjang Utara, Kuala Lumpur. Prepared for Jabatan Pengurusan Sisa Pepejal (JPSPN) and Kementerian Perumahan dan Kerajaan Tempatan (KPKT). Universiti Teknologi Malaysian, 81310 UTM Skudai.

Wan Yaacob, 2011. Groundwater Modeling Report for Taman Beringin Landfill Jinjang Area, Kuala Lumpur, Malaysia.

White, P.A., Y.S., Hong, D., Murray, D., D.M. Scott and H.R. Thorpe, 2003. Evaluation of regional models of rainfall recharge to groundwater by comparison with lysimeter measurements, Canterbury, New Zealand. J. Hydrol., 42: 39-64.
Zheng, C., 1990. MT3D, A modular three-dimensional transport model for simulation of advection, dispersion and chemical reactions of contaminants in groundwater systems. Report to the US Protection Agency, Robert S. Kerr Environmental Laboratory Ada, Oklahoma 74820.

Zhou, Y. and W. Li., 2011. A review of regional groundwater flow modeling. Geosci. Frontiers, 2: 205- 214. DOI: 10.1016/j.gsf.2011.03.003 